\title{
Introduction
}

\section{Queer Death Studies: Coming to Terms with Death, Dying and Mourning Differently. An Introduction.}

By Marietta RadomsKa, Tara Mehrabi and Nina LyKKe
I

the $20^{\text {th }}$ century death becomes the catalyst undermining the foundations of Western philosophy and cultural theory. As the Frankfurt School, postmodernism and poststructuralism argue, the Enlightenment institution of reason and the idea of the rational human subject can no longer hold after the horrors of the Holocaust, Gulag, and two world wars (e.g. Horkheimer and Adorno 2002; Lyotard 1988). These perspectives recognise the failure of the Enlightenment humanist idea of the subject with its autonomy and rationality in the face of massacres exercised in the past century all around the world. Still, they tend to leave out the fact that, as Tasmanian scholar Greg Lehman (1997) emphasises, for indigenous peoples death has remained "life's quiet companion" since the very outset of the colonial conquest. In the second half of the $20^{\text {th }}$ century, the period of Cold War and nuclear arms race, the accompanying issues of threats from nuclear winter and waste and 
its impact on the present and future generations, as well as continued post/colonial violence, extraction and slaughter pushed questions of death and genocide to visible planetary scale issues which, helped by the unfolding of global media networks, became crucial components of both public discourse and the cultural and social imaginaries along these lines.

Yet, over the past decade, a shift has taken place in tandem with the ecological and climate change crises becoming visible also on a planetary scale. In the Global North, during the cruelly optimist neoliberal 'endof-history' and 'end-of-nuclear-war-threat' era after the fall of the Berlin Wall and the Soviet Union, death has sometimes been perceived by the white middle classes as something 'distanced' in temporal, social, and/or geographical terms. However, with the accelerating impacts of toxic environments, the global warming and climate change broadly speaking, on the one hand, and the rise of far-right political movements in Europe and beyond, on the other, death is becoming part and parcel of reality in new ways - an affair intimately weaved in the tissues of everyday life. In the context of the current environmental crises, the degradation of natural resources transforms certain habitats into unliveable spaces, affecting thus both human and nonhuman communities and ecosystems. Simultaneously, social and economic inequalities and geopolitical, social and symbolic violence expose differential vulnerabilities of groups and individuals. Both global and local mechanisms of necropolitics (Mbembe 2003) exert their power over the lives and deaths of populations, making some deaths more grievable than others (Butler 2004), while unsustainable living conditions and environments contribute to increased mortality rates and the extinction of species. At the same time, modern biopolitical agendas with 'cruel optimism' (Berlant 2011) keep promising the eventual abolishing of death through technoscientific advances. All these issues not only raise the question of what it means to live in ecological and social proximities of death, but also make us realise that concepts, articulations and stories at hand are insufficient to account for the complex problematics of death, dying, and mourning in the present times, when some communities and individuals are still deemed to be "worth less than" (Braidotti 1994) others.

While natural sciences emphasise the interdependence of human and the environment, Western cultural imaginaries keep drawing a dividing line between humans and nonhuman others, particularly visible in relation to death. In such a context, dying is perceived simultaneously as a process common to all organisms and as an event that distinguishes the human from other creatures (cf. Schopenhauer [1844] 1969; Heidegger [1953] 2010; Calarco 2008); the human subject is supposed to potentially be privileged by having an afterlife, either, in the Christian tradition, in the shape of an immortal soul, or in the secular-humanist sense as a posthumously memorised subject. A prerequisite for this kind of privileged afterlife is that the passed away subject is not located beyond the boundaries of what is considered grievable (Butler 2004) in terms of citizenship, migrant status, geopolitical positioning, racialisation, class, gender, sexuality, dis/ability, etc. In addition to these clusters of hierarchical divisions between humans and nonhumans, and between grievable and non-grievable lives, it is also to be noted how the biopolitical agendas of Western modernity tend to present the death (of privileged citizens) as something to be eradicated altogether in favour of survival in a secular biomedical perspective.

\section{DEATH STUDIES AND \\ QueErfeminist CRITIQUES}

Arguably, the questions of death and dying have been present in Western philosophy and cultural narratives since antiquity (e.g. 
Plato 1914, Apology; Aristotle 1984, The Nicomachean Ethics; Epicurus 1926, Letter to Menoeceus). While these perspectives explore both ontological and axiological aspects of death, they are primarily concerned with the death of human individuals, seen from the point of view of the normative sovereign subject (e.g. Bradley, Feldman and Johansson 2013). Another line of Western research on death is related to literary, visual, and musical studies, investigating artistic articulations of affective landscapes of death, dying and mourning, but again with a strong focus on human death, understood as exceptional (e.g. Guthke 1999). Furthermore, questions around death, human remnants and the cultural and medical aspects of dying have been studied from anthropological, sociological, historical, and psychological perspectives, next to the biomedical ones. Since its establishment as a research field in the 1970s, Death Studies has drawn attention to the questions of death, dying and mourning as complex and multifaceted phenomena that require interdisciplinary approaches (e.g. Fahlander and Oestigaard 2008; Åhrén 2009; Gunnarson and Svanaeus 2012). Three academic journals: Death Studies, Omega and Mortality mark the field.

Yet, the engagements with death, dying and mourning constitutive of conventional Death Studies' research (e.g. Kearl 1989; Kasher 2007), need to be taken critically further, among others, where they have been constrained by normative notions of the human subject; the human/nonhuman divide; continuing bonds; family relations and communities; rituals; and experiences of mourning and bereavement. Individuals who do not fulfil the conditions of the normative idea of the human (usually imagined to be white, middle-class, heterosexual, cisgendered, and able-bodied) tend to be ignored in dominant stories on death, loss, grief and mourning. Moreover, the current environmental crisis seems to produce new kinds of planetary consciousness about liv- ing in ecological and social proximities to extinction, which also gives rise to demands for new kinds of stories of death, dying and mourning.

The emerging field of Queer Death Studies (QDS), which the present special issue contributes to fostering, tries to overcome the problems of traditional Death Studies by addressing issues of death, dying, mourning and afterlife in a queering, relentlessly norm-critical mode, questioning ontologies, epistemologies and ethics, as well as bio- and necropolitical agendas, while affirmatively looking for alternatives. This implies, for example, attending to issues of diverse cultural, socio-political, historical and economic conditions; to entangled relations between human and the environment in the context of the Anthropocene; and to differential experiences of marginalised communities and individuals excluded from hegemonic discourses on death, loss, grief, and mourning. Queer Death Studies draws critical attention to discourses on death and mourning associated, for example, with heteronormative models of family bonds; with chrononormative modes of life; with norms for intergenerational relations; with 'proper' responses to biopolitical regimes of healthand life-normativity; with normative demands to consider life-threatening diseases from the perspective of a heroic battle against an 'enemy' rather than trying to engage with the life/death thresholds in less rigid and more (self-)caring and -loving ways. Along these lines Queer Death Studies also focuses on contemporary forms of necropolitics, i.e. mechanisms of power that force certain bodies into liminal spaces between life and death (as in the case of refugees whose lives in detention camps across Europe are turned into the state of 'social death' (Mirzoeff 2019)).

Thus, QDS emerges as a transdisciplinary field of research that critically, (self) reflexively and affirmatively investigates and challenges conventional normativities, as- 
sumptions, expectations, and regimes of truths that are brought to life and made evident by death, dying and mourning.

QDS has been consolidated through the workings of Queer Death Studies Network $(\mathrm{QDSN})^{1}$ that was officially launched at the G16: Swedish National Gender Research Conference in Linköping in 2016. To date, the network has hosted three international workshops and has worked on a series of joint publications (the present volume and a special issue of Australian Feminist Studies forthcoming in spring 2020, among others), which all have contributed to further development of transversal dialogues among academics, activists, artists and other practitioners.

By bringing together conceptual and analytical tools grounded in feminist materialisms and feminist theorising broadly speaking (e.g. Braidotti 2006; MacCormack 2012; Franklin and Lock 2003), queer theory (e.g. Haritaworn, Kuntsman and Posocco 2014; Ensor 2015) and decolonial critique (e.g. Fanon 1965; Mignolo 2011; Tlostanova and Mignolo 2012; Anzaldua 2015), Queer Death Studies strives to advance methodologies and understandings that critically and creatively attend to the problem of death, dying and mourning in current environmental, cultural, social, bioand necropolitical contexts.

\section{QueEring Death Studies}

While searching for alternative articulations, silenced narratives and different stories, Queer Death Studies unpacks and questions normativities (Chen 2012; Sandilands and Erickson 2012) that often frame contemporary discourses on death, dying and mourning. In the context of QDS, to queer issues of death, dying and mourning means to unhinge certainties, "undo normative entanglements and fashion alternative imaginaries" beyond the exclusive concern with gender and sexuality, often associated with the term 'queer' (Giffney and
Hird 2008, 6). In other words, 'queer' in QDS refers to both: (1) a noun/an adjective employed in researching and narrating death, dying and mourning in the context of queer bonds and communities, where the subjects involved, studied or interviewed and the relations they are involved in are recognised as 'queer'; and (2) a verb/an adverb that describes the processes of going beyond and unsettling (subverting, exceeding) binaries and given norms and normativities. Consequently, 'queer' becomes both a process and a methodology that is applicable and exceeds the focus on gender and sexuality as its exclusive concerns. As Giffney and Hird emphasise, queer theorising is characterised by "a spirit of critique (...) a respect for difference, dedication to self-reflexivity, and drive towards revision", combined with 'openness' to different frameworks and analytical tools as well as "a commitment to foregoing ownership of the word 'queer"' $(2008,4)$. In its critical, creative and transdisciplinary efforts, QDS strives to challenge understandings of death, dying and mourning anchored in and structured by the hegemony of heteronormative narratives (e.g. Lykke 2015; 2018; Alasuutari 2018, forthcoming); of the white Western subject and its relations (e.g. Snorton and Haritaworn 2013; Haritaworn, Kuntsman and Posocco 2014; Lykke 2019); human exceptionalism (MacCormack forthcoming 2019; Mehrabi 2016; Radomska 2018; forthcoming 2019; Lykke forthcoming 2020); and technologisation/medicalisation of death (e.g. Adrian forthcoming 2020), among others. Consequently, QDS opens up a space where death, dying and mourning are considered critically, creatively, 'transversally' (Guattari 2008) and in an ecological manner, that is, "going beyond the separate boxes of disciplines (...) and remaining attentive to the ever-changing geo-political, social, cultural and environmental conditions" (Radomska 2017, 379). 


\section{Three Overarching Themes}

In particular, in this special issue we aim to rethink death, dying and mourning through theoretical and methodological modes of queering. These modes are mobilised under three overarching themes: (1) queer (necro)politics, which focuses not only on regimes and technologies that subjugate "life to the power of death" (Mbembe 2003, 39), while rendering some lives more grievable than others, but also, on queer modes of resistance; (2) posthuman ethico-politics of death, which seeks to problematise and undermine human exceptionalism, while exploring human/nonhuman relationalities in the context of death and dying; and (3) queering death and mourning, which concentrates on nonnormative practices of remembering and mourning the dead.

The issue opens with three articles which reflect on the multi-layered power relations that enact unjust modes of dying, un/grievable deaths and un/liveable lives within homonationalist, heteronormative and cis-normative frames governing life and death in contemporary society. In the article The trouble with 'truth'. On the politics of life and death in the assessment of queer asylum seekers, Marie Lunau explores death and dying in the context of queer asylum seeking in Denmark. Conducting in-depth interviews with asylum seekers and drawing on their lived experiences, Lunau explores the 'necropolitcs' (Mbembe 2003) of the asylum-seeking procedures and the white heteronormative assumptions about 'true' queerness that manage the life and death of her informants in these processes. She argues that the asylum seeking process has the performative power not only to kill or to let someone die but to keep a person in a state of 'slow death' (Berlant 2007) and non-living as their "hope of life, asylum and citizenship are infused with deathly practices and normative imaginaries of truthful queerness".

In their discussion of queer (necro)poli- tics, titled Constructing Injustice Symbols in Contemporary Trans Rights Activisms, David Myles and Kelly Lewis focus on mourning practices related to the unjust death of trans* individuals. Using Judith Butler's concept of 'un/grievable lives' (2004), they analyse the iconic deaths of Jennifer Laude who was murdered by an American soldier in the Philippines in 2014; Hande Kader, a Turkish activist who was raped and murdered in 2016; and Marsha P. Johnson, an American activist who died in 1992 under suspicious circumstances. The two authors situate their analyses at the intersection of online Death Studies and activism, discussing how through the use of the social media and other online platforms - trans* rights activists, make (online) grief politically productive. In other words, they show that ritualised forms of visual practices such as circulating the images of the deceased with hashtags, for instance \#JusticeForJennifer, \#JusticeForHande, and \#JusticeForMarsha enacts trans* deaths as not only privately grievable but deserving to be publicly mourned. They argue that such public mourning brings to the fore the brutality of crimes against trans* individuals and constructs the murders as symbols of injustice which highlight the inability of white, cis-normative and heteronormative justice systems to treat these deaths on an equal ground. At the same time, (online) public mourning makes these deaths visible across geopolitical boundaries and creates communities through solidarity and shared mourning.

The third piece that queers (necro)politics in this issue is an artistic contribution by Danish underground death metal band Kami who describes their music as 'near death metal': nearly dead but not quite yet. Throughout their lyrics, and in the accompanying introduction, they explore topics of loss, death, transformation, futility and anger. In their piece Fleshraven, inspired by Edgar Allan Poe's famous gothic poem The 
Raven, Derrida's notion of a 'monstrous future' and Michel Foucault's critical notions of power are employed in order to explore the inhuman policies regarding boat refugees in the Mediterranean.

The other two artistic pieces by Kami: The Dark Multiple and The End are grounded in the second theme of this special issue, that is, the posthuman ethicopolitics of death. Moving away from the human subject ('always already' marked by social axes of power, such as gender and race), these two artistic pieces undo the singular subject in favour of a more-than-human assemblage of microbial and microscopic entities, which invites a rethinking of life and death as always already intertwined. While The End takes extinction in the face of environmental changes - 'the end of the world' - as well as decay and decomposition seriously, it does not hold nostalgia for the modernist human subject. Instead, it approaches death as transformation and a material process in which death not only brings life, but where "death is life".

Contributing to a posthuman ethicopolitics of death that queers the binaries of life/death, and the human/nonhuman, Vanbasten de Araújo rethinks these notions in the article 'Life Without Humankind' queer death/life, plastic pollution, and extinction in "An Ecosystem of Excess". The article puts focus on artist Pinar Yoldas's $A n$ Ecosystem of Excess (EOE) (2014). As presented in the artwork, what happens if life emerges out of the plastic debris-filled ocean caused by the capitalist consumerist culture that is pushing life to the brink of extinction? De Araújo argues that such artistic works are not only bringing together art, science and speculative imagination of potential futures, but also enact forms of activism and concrete political interventions here and now that encourage us to rethink the relation between the human and the nonhuman in terms of ecosystems. In other words, such artworks are "forces of resistance" that remind us that no one lives or dies alone, but we, human and nonhuman, are all interconnected. De Araújo argues that such forms of resistance queer death, life, and extinction beyond the hegemonic representations "in which the human experience prevails". In queering the temporalities of extinction, in which human extinction is no longer the marker of the end of the world, de Araújo explores the potentiality of "a future ecosystem without the human".

Thinking about death in the Anthropocene is also present in Salome Rodeck's article Dying with "Infinity Mushrooms" Mortuary Rituals, Mycoremediation and Multispecies Legacies, which takes as its point of departure that it is not only plastic that is polluting the environment after all but also contemporary funeral practices. Inspired by artist and designer Jae Rhim Lee's "Infinity burial project", Rodeck discusses infinity mushroom as an alternative 'greener' burial method that can potentially limit the polluting effects of contemporary Western funeral practices. Rodeck argues that infinity mushrooms problematise the cultural taboos of corporeal decomposition that threatens human exceptionalism and instead places the human corpse in nature as part of the ecosystem, queering the binary between life and death. Infinity mushrooms, she writes, takes the "material reality of decaying and the implications of dying in a polluted world" as its point of departure. Thinking together with scholars such as Stacy Alaimo, Donna Haraway and Anna Tsing, Rodeck elaborates on the inseparability of human existence from "the flow of matter, toxic and otherwise", while simultaneously highlighting that humans need (microbial) others not only in life but also in death. Rodeck suggests that thinking with mushrooms as 'oddkin' (Haraway 2016) generates new practices of mourning that understand death as a multispecies material transformation.

Thinking about mourning as a posthuman issue is also present in Agnieszka Kot- 
wasińska's article Beyond Death and Mourning in "A Dark Song" and "We Are Still Here" that contributes to the third theme in this special issue: queering death and mourning. Kotwasińska analyses two recent horror movies: A Dark Song (2016) and We Are Still Here (2015). She discusses how staying with spectral soundscapes in these movies queers ontologies of death when the eye is denied the pleasure of seeing/knowing. On the one hand, she critically reflects on the heteronormative and gendered aspects of grief represented in these movies. On the other hand and turning her analytical focus from the visual and the gaze to the sound and affect, Kotwasińska asks how we can "think/feel death differently" beyond ocular modes of knowing vital to the Western epistemic culture. Drawing on both Ewa Domańska's concept of necrovitalism (2017) and Rosi Braidotti's neovitalism (2006) and reading them through the affective medium of sound, Kotwasińska shows how, in these movies, death is a continuum of zoe rather than an "ambiguous end of bios".

Katja Herges' article From BecomingWoman to Becoming-Imperceptible: SelfStyled Death and Virtual Female Corpse in Digital Portraits of Cancer is also situated within a neovitalist conceptualisation of death, dying and mourning, exploring boundaries between personal death of a human subject and death as an impersonal becoming-imperceptible and becomingcorpse (e.g. Braidotti 2013). In the article, Herges explores links between femininity, death, and impersonalised (Western) icons of the dead female body, and how they are critically and norm-disruptively enacted in multiple ways in a series of camp photoshoots (published, among others, as social media portraits), which 19-year old Nana Stäcker and her mother, Barbara Stäcker, collaboratively constructed, while Nana was dying from cancer (Ewing sarcoma). Herges focuses on the ways in which the photo-shoots articulate processes of (self-) styling, staging and aesthecising Nana's becoming corpse, her move from personalised human subject to impersonal corpse. But, according to Herges, Nana is also reclaiming agency, self-care and relationality, while she - together with her mother and other relations - (self-)styles her death through queer assemblages of postmodern fashion photography, cancer narratives, gothic representations of the female corpse, and social media self-styling. Borrowing Braidotti's concepts of becoming-woman and becoming-imperceptible, Herges argues that Nana's images provide a posthuman articulation of a queer feminine subjectivity that helps Nana and her mother in the process of mourning and "reconceptualising individual death into an impersonal life-death continuum".

The last contribution, Mourning $M y$ Mother: An Exploration of the Complex Emotions Elicited by the Terminal Illness of an Estranged Parent, by Anne Bettina Pedersen queers mourning from an intergenerational perspective, disrupting norms for how a dutiful daughter normatively is expected to enact unconditional compassion, relate to, care for and mourn her mother, even if the encounters with the mother since childhood have been perceived as toxic and abusive. In the article, based on an autophenomenographic analysis, which combines a deeply personal and highly political approach, Pedersen reflects on the relationship with her estranged mother on the occasion of the message that the mother had been diagnosed with terminal cancer. Through autobiographical, poetic vignettes, Pedersen explores queer modes of grieving and mourning that go beyond the normative frames of mother-daughter relations. She brings to the fore the complexity and multiplicity of emotions that are silenced and undertheorised because of cultural taboos associated with family estrangement, especially between daughter and mother. She discusses the potential vulnerability that is intrinsic to relations of 
care with an estranged mother, and the harm that a process of (re)mourning and (re)grieving potentially might generate. In other words, through poetic reflection and autophenomenographic analysis, Pedersen suggests that "denial of care for an estranged parent translates into self-care and self-preservation", as well as care for her own daughter.

Marietta Radomska, PhD, Postdoc, Linköping University, Sweden (Gender Studies); Visiting Postdoc, Univ. of Helsinki, FI (Art History); Codirector of The Posthumanities Hub; founder of The Eco- and Bioart Research Network; founding member of Queer Death Studies Network and Network for ECOcritical and DECOlonial Research; philosopher and posthumanities scholar.

Tara Mehrabi, $\mathrm{PhD}$, is a lecturer at the Centre for Gender Research at Karlstad University, Sweden and a founding member of Queer Death Studies Network. She is a feminist technoscience-, transdisciplinary gender studies- and posthumanities scholar. Her current research interests are issues of body, health, technology and life/death.

Nina Lykke, Prof. Em. Dr. Phil., Gender Studies, Linköping University, Sweden; founding member of networks for Queer Death Studies, ECOcritical and DECOlonial Research. Current research: death, mourning, and spirituality in posthuman, queerfeminist and decolonial perspectives; queering of cancer; autophenomenography; poetic writing; intersectionality debates.

\section{Note}

See: https://queerdeathstudies.wordpress.com/ (accessed 31 May 2019)

\section{REFERENCES}

- Adrian, S. W. Forthcoming 2020. Diffracting Broken Hearts: Living Response-ably with Technologies of Death and Dying at the Beginning of Life. Australian Feminist Studies.

- Åhrén, E. 2009. Death, Modernity and the Body:
Sweden 1870-1940. Rochester: University of Rochester Press.

- Alasuutari, V. 2018. Queerit perheet ja läheisen kuolema [Queer Families and the Death of a Loved One]. In: Eerola, P. and Pirskanen, H. eds. Perhe ja tunteet. Helsinki: Gaudeamus, 185-201. - Alasuutari, V. Forthcoming. Queer-ystävyys perheenä ja tukiverkostona [Queer Friendship as a Family and a Support Network]. In: Lahti, A., Aarnio, K., Moring, A. and Kerppola-Pesu, J. eds. Perhe- ja läheissubteet sateenkaaren alla. [Family and Kin Bonds under the Rainbow] Helsinki:

Gaudeamus.

- Anzaldua, G. E. 2015. Light in the Dark/Luz en Lo Oscuro: Rewriting Identity, Reality, Spirituality. Durham: Duke University Press.

- Aristotle. 1984. Nichomachean Ethics. In:

Barnes, J. ed. The Complete Works of Aristotle: The Revised Oxford Translation. Princeton: Princeton University Press 3718-4010.

- Berlant, L. 2011. Cruel Optimism. Durham:

Duke University Press.

- Bradley, B., F. Feldman, and Johansson, J. 2013.

The Oxford Handbook of Philosophy of Death. Oxford: Oxford University Press.

- Braidotti, R. 1994. Nomadic Subjects: Embodiment and Sexual Difference in Contemporary Feminist Theory. New York: Columbia University Press.

- Braidotti, R. 2006. Transpositions. Cambridge and Malden: Polity.

- Braidotti, R. 2013. The Posthuman. Cambridge and Malden, MA: Polity Press.

- Butler, J. 2004. Precarious Life: The Powers of Mourning and Violence. London: Verso.

- Calarco, M. 2008. Zoographies: The Question of the Animal from Heidegger to Derrida. New York: Columbia University Press.

- Chen, M. Y. 2012. Animacies: Biopolitics, Racial Mattering and Queer Affect. Durham: Duke University Press.

- Domańska, E. 2017. Nekros. Wprowadzenie do ontologii martwego ciata [Necros: An Introduction to the Ontology of Human Dead Body and Remains]. Warsaw: Wydawnictwo Naukowe PWN. - Ensor, S. 2016. Terminal Regions: Queer Ecocriticism at the End. In: Hunt, A. and Youngblood, S. eds. Against Life. Evanston IL: Northwestern University Press, 41-62.

- Epicurus. 1926. Letter to Menoeceus. In: Bailey. C. ed. The Extant Remains. Oxford: Oxford University Press, 327-343.

. Fahlander, F. and Oestigaard, T. 2008. The Materiality of Death: Bodies, Burials, Beliefs. Oxford: Archaeopress. 
. Fanon, F. 1965. A Dying Colonialism. New York: Grove Press.

- Franklin, S. and Lock, M. 2003. Remaking Life of Death: Toward an Anthropology of the Biosciences. Santa Fe: School of American Research Press.

- Giffney, N. and Hird, M. J. 2008. Introduction: Queering the Non/Human. In: Giffney, N. and Hird, M. J. eds. Queering the Non/Human. London: Palgrave, 1-16.

- Guattari, F. 2008. The Three Ecologies. London: Continuum.

- Gunnarson, M. and Svenaeus, F. 2012. The Body as Gift, Resource and Commodity: Exchanging Organs, Tissues and Cells in the 21st Century. Stockholm: Södertorn Studies in Practical Knowledge. - Guthke, K. S. 1999. The Gender of Death: A Cultural History in Art and Literature. Cambridge: Cambridge University Press.

- Haraway, D. J. 2016. Staying with the Trouble: Making Kin in the Chthulucene. Durham: Duke University Press.

- Haritaworn, J., Kuntsman, A. and Posocco, S. 2014. Queer Necropolitics. New York: Routledge. - Heidegger, M. 2010 [1953]. Being and Time. Albany: State University of New York Press.

- Horkheimer, M. and Adorno, T. W. 2002. Dialectic of Enlightenment: Philosophical Fragments. Stanford: Stanford University Press.

- Kasher, A. ed. 2007. Dying and Death: Inter-Disciplinary Perspectives. Amsterdam and New York: Rodopi.

- Kearl, M. C. 1989. Endings: A Sociology of Death and Dying. New York: Oxford University Press.

- Lehman, G. 1997. Life's Quiet Companion. Island. (69), 54-61.

- Lykke, N. 2015. Queer Widowhood. Lambda Nordica. (4), 87-111.

- Lykke, N. 2018. When death cuts apart: On affective difference, compassionate companionship and lesbian widowhood. In: Juvonen, T. and Kohlemainen, M. eds. Affective Inequalities in Intimate Relationships. New York, London: Routledge, 109-125.

- Lykke, N. 2019. Making Live and Letting Die: Cancerous Bodies between Anthropocene Necropolitics and Chthulucene Kinship. Environmental Humanities. 11(1), 108-136. DOI: https://doi.org/10.1215/22011919-7349444 - Lykke, N. Forthcoming 2020. Co-becoming with Diatoms: Between Posthuman Mourning and Wonder in Algae Research. Catalyst. Feminism, Theory, Technoscience. Special Issue: Plantarium.
- Lyotard, F. 1988. The Differend: Phrases in Dispute. Manchester: Manchester University Press. - MacCormack, P. 2012. Posthuman Ethics: Embodiment and Cultural Theory. Surrey and Burlington: Ashgate.

- MacCormack, P. Forthcoming 2019. The Abuman Manifesto: Activism for the End of the Anthropocene. London: Bloomsbury.

- Mbembe, A. 2003. Necropolitics. Public Culture. 15(1), 11-40. DOI:

https://doi.org/10.1215/08992363-15-1-11

- Mehrabi, T. 2016. Making Death Matter: A Feminist Technoscience Study of Alzheimer's Sciences in the Laboratory. Linköping: Linköping University Press.

- Mignolo, W. D. 2011. The Darker Side of Western Modernity: Global Futures, Decolonial Options. Durham: Duke University Press.

- Mirzoeff, N. 2019. 'Social Death' in Denmark. The Nation. [Online]. January 20. [Accessed January 30 2019]. Available from:

https://www.thenation.com/article/denmarkrefugees-asylum-europe/.

- Mortimer-Sandilands, C. and Erickson, B. 2010. Queer Ecologies: Sex, Nature, Politics, Desire.

Bloomington: Indiana University Press.

- Plato. 1914. Eutyphro. Apology. Crito. Phaedo.

Phaedrus. Cambridge, MA: Harvard University Press.

- Radomska, M. 2017. Non/living Matter, Bioscientific Imaginaries and Feminist Technoecologies of Bioart. Australian Feminist Studies. 32(94), 377-394. DOI:

10.1080/08164649.2017.1466649

- Radomska, M. 2018. Promises of Non/Living Monsters and Uncontainable Life. Somatechnics. 8(2), 215-231. DOI:

https://doi.org/10.3366/soma.2018.0252

- Radomska, M. Forthcoming 2019. Queering Ecologies of Death. Online DOSSIER for EcoFutures Festival. London, UK.

- Schopenhauer, A. 2010 [1844]. The World as Will and Representation. Cambridge: Cambridge University Press.

- Snorton, C. R. and Haritaworn, J. 2013. Trans Necropolitics: A Transnational Reflection on Violence, Death and the Trans of Color Afterlife. In: Stryker, S. and Aizura, A. Z. eds. The Transgender Studies Reader 2. New York: Routledge, 66-76. - Tlostanova, M. V. and Mignolo, W. D. 2012. Learning to Unlearn: Decolonial Reflections from Eurasia and the Americas. Columbus, $\mathrm{OH}$ : The Ohio State University Press. 